\title{
Martina Bečvářová
}

ORCID 0000-0001-7207-4330

Institute of Applied Mathematics

Faculty of Transportation Sciences

Czech Technical University in Prague

(Prague, Czech Republic)

becvamar@fd.cvut.cz

\section{Stanisław Domoradzki}

ORCID 0000-0002-6511-0812

Institute of History, University of Rzeszów

(Rzeszów, Poland)

domoradz@ur.edu.pl

\section{Mathematics in the interwar period in Central-Eastern Europe. The report on an international research project for the years 2018-2020}

\begin{abstract}
In the article, we will show the main important results of the international research project The impact of WWI on the formation and transformation of the scientific life of the mathematical community. It was supported by the Czech Science Foundation for the years 2018-2020 and brought together ten scientists from five countries
\end{abstract}

\begin{tabular}{|c|c|c|c|c|}
\hline $\begin{array}{l}\text { PUBLICATION } \\
\text { INFO }\end{array}$ & $\begin{array}{c}\text { Ptudia } \\
\text { Cistoriae } \\
\text { cientiarum }\end{array}$ & $\begin{array}{r}\text { e-ISSN 2543-702X } \\
\text { ISSN 2451-3202 }\end{array}$ & 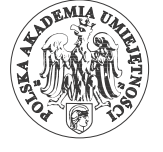 & $\begin{array}{c}\boldsymbol{\varnothing} \\
\text { DIAMOND } \\
\text { OPEN ACCESS }\end{array}$ \\
\hline \multicolumn{5}{|c|}{$\begin{array}{l}\text { CITATION } \\
\text { Bečvářová, Martina; Domoradzki, Stanisław 2021: Mathematics in the interwar period in Central-Eastern } \\
\text { Europe. The report on an international research project for the years 2018-2020. Studia Historiae } \\
\text { Scientiarum 20, pp. 895-937. DOI: } 10.4467 / 2543702 X S H S .21 .026 .14057\end{array}$} \\
\hline \multicolumn{2}{|c|}{$\begin{array}{l}\text { RECEIVED: } 19.05 .2020 \\
\text { ACCEPTED: } 29.06 .2021 \\
\text { PUBLISHED ONLINE: } 13.09 .2021\end{array}$} & $\begin{array}{l}\text { ARCHIVE } \\
\text { POLICY } \\
\text { Green SHERPA/ } \\
\text { RoMEO Colour }\end{array}$ & 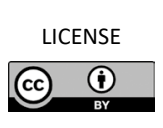 & $\begin{array}{l}\text { Crossref } \\
\text { Similarity Check } \\
\text { Powered by itrenticate }\end{array}$ \\
\hline
\end{tabular}


(Czech Republic, Poland, Slovakia, USA, and Ukraine) and used the collaboration with historians of mathematics and mathematicians from many other European countries. We will discuss our motivation for the creation of the project, our methodological and professional preparations which profited from the international composition of the team and its longtime collaborations, profound specializations and experiences of the team members, and their deep and long-term studies of many archival sources and basic published works. We will present our choice of the general research trends, our definition of the scientific questions, and our determination of the main topics of our studies. We will describe our most important results (books, articles, visiting lectures, presentations at national and international conferences, seminars and book fairs, exhibitions, popularizations of the results between students, teachers, mathematicians, historians of sciences, and people who love mathematics and its history). We will analyze the new benefit that the project created for the future, for example, good platforms for future international research and cooperation, the discovery of many new interesting research questions, problems, and plans.

Keywords: report on the international research project, history of mathematical communities and schools, interwar period, Central-Eastern Europe

\title{
Matematyka w dwudziestoleciu międzywojennym w Europie Środkowo- -Wschodniej. Raport z międzynarodowego projektu badawczego za lata 2018-2020
}

\begin{abstract}
Abstrakt
W artykule zaprezentujemy najważniejsze wyniki międzynarodowego projektu badawczego The impact of WWI on the formation and transformation of the scientific life of the mathematical community, który w latach 2018-2020 był wspierany przez Czech Science Foundation i skupił prace dziesięciu badaczy z pięciu krajów (Czechy, Polska, Słowacja, USA i Ukraina), którzy współpracowali z historykami matematyki i matematykami z innych krajów europejskich. Przedstawimy nasze motywacje związane $z$ powstawianiem
\end{abstract}


projektu, przygotowania metodyczne i doświadczenia zawodowe, które wykorzystały międzynarodowy skład zespołu i jego wieloletnią współpracę, unikatowe doświadczenia i stała pracę nad źródłami archiwalnymi, jak również dorobek naukowy. Przedstawimy wybór naszych ogólnych kierunków badawczych, pytania badawcze oraz zaprezentujemy główne tematy badawcze projektu. Podamy najważniejsze wyniki prac projektowych (książki, artykuły, wykłady na zaproszenie organizatorów konferencji, prezentacje na krajowych i zagranicznych konferencjach i seminariach oraz targach książki, wystawy, popularyzacje wyników wśród uczniów, nauczycieli, matematyków, historyków nauki i osób interesujących się matematyką i jej historia). Dokonamy analizy przyszłych korzyści, jakie projekt stworzył np. nowe platformy dla kolejnych międzynarodowych badań i wspólpracy oraz odkrycie nowych, interesujących pytań badawczych, problemów i planów.

Słowa kluczowe: sprawozdanie z, miedrynarodowego projektu badawczego, historia spoteczności matematycznych i szkót matematycznych, dwudziestolecie międzywojenne, Europa Środkowo-W schodnia

\section{The historical background of the project}

In 1914, World War I - the first global world war - broke out and began a process of huge world change. From 1914 until 1918, European countries suffered greatly from the conflict and its consequences: difficult and long-lasting battles, countless victims, seriously injured and handicapped young people, destroyed countries, disrupted economies and social life, insufficiency of food, problems with supplies and consumer goods, poor health and social care, interruption of personal careers or studies, lack of housing and lecture/study rooms (which had been turned into military hospitals), lack of international contacts, travel possibilities and foreign literature, and finally, the decreasing number of high school students.

At the end of the war, the map of Europe underwent major changes and several new states (Czechoslovakia, Poland, Hungary, Austria, etc.) were created. Diplomatic communication and collaboration between nations changed due to the Treaty of Versailles, the Russian Revolution, and the subsequent isolation of the USSR, social disturbances, and the economic crisis. The processes of national emancipation started, as 
well as the emancipation of women in science. Later, the new economic crisis, religious and nationalistic persecutions, the rise of anti-Semitism, and political purges opened the door for the next bloody conflict, World War II.

These political, economic, social, and cultural phenomena strongly influenced the development of science and technology, academic and research institutions, universities, and the system of higher education.

The role of WWI and its influence on the scientific life in the interwar period, especially on the mathematical community, has been studied in Western and Southern Europe (Great Britain, France, Belgium, Germany, Italy, Spain, and Greece) and in the USA. These existing studies (special case studies, articles in journals and proceedings, as well as extensive monographs) are rather fragmented. They often analyze separately the historical roots of changes by considering special local principles (e.g., a national, regional, or religious approach), describe only the historical aspects with an emphasis on political and social perspectives, or study only the scientific point of view with a superficial or absent historical context (special studies on mathematics, natural sciences, medicine, etc.).

The study of the interwar development of the mathematical communities in Central and Eastern Europe, their scientific achievements, international collaboration, and teaching activities, has suffered from the disinterest of historians in general, historians of mathematics and mathematicians, although these topics represent an indispensable part of European and world science, culture and history. This has to do with the significantly limited access to archive sources, the widely-held opinion that the majority of sources had not been preserved, and the fact that "these themes" were not popular for several reasons. Moreover, the study of the development of mathematical communities and scientific societies does not usually belong to central topics of historical research.

\section{The motivation for the project}

The most important impulse for the preparation of the project came at the international conference titled „Minerva armata. Le università e la Grande guerra" [Minerva armata. Universities and the Great War], which took part in the beautiful Teatro Millepini in Asiago (Italy) from $27^{\text {th }}$ to $31^{\text {st }}$ July 2016. It was organized by the Centro interuniversitatio per 
storia delle università italiane and it was prepared by Gian Paolo Brizzi, Elisa Signori and Luigi Pepe. It is important to emphasize that the small town of Asiago was symbolically chosen as the conference venue. Asiago is situated in the surrounding plateau region the Altopiano di Asiago in the Province of Vicenza in the Veneto region of northeastern Italy. The town was the site of a major battle between Austrian and Italian forces on the Alpine Front of WWI. The international conference focused on WWI and its impact on scientific and academic life in Europe, especially in the West and South of Europe. At the conference, there were many interesting lectures, discussions, excursions, and impulses for thinking about future research. They made us realize that the impact of WWI on the after-war development of the life of the academic communities in the West and South of Europe is very well analyzed and described but the situation in Central or Eastern Europe was outside of the interest of historians. ${ }^{1}$

The second impulse came at the $37^{\text {th }}$ International Conference on the History of Mathematics, which took part in Poděbrady in the Czech Republic from $19^{\text {th }}$ to $23^{\text {rd }}$ August 2016. At the traditional summer international conference, historians of mathematics and mathematicians from the Czech Republic, Poland, Slovakia, Hungary, Ukraine, and the USA met every year or every two years. ${ }^{2}$

Long and deep discussions ensued between Czech and foreign colleagues (potential members of the team) on a future project on the impact of WWI on the formation and transformation of the scientific life of the mathematical community in Central and Eastern Europe. It was where our first project preparations started, for example, discussions on the old and new literature, fundamental archival sources, general research topics, and preliminary analyses of modern trends. The preparatory works continued from the summer of 2016 until the spring of 2017. Many emails, video calls, and meetings took place at this time; many suggestions were proposed, discussed, rejected, transformed, and finally accepted.

1 For more information on the programme of the international conference, see Centro interuniversitario per la storia delle università italiane - CISUI 2016. For other information, see Brizzi, Signori (eds.) 2017.

2 For more information on the international conference on the history of mathematics, see Bečvář 2016. 
The team drew inspiration from various national pieces of literature describing the development of European and world mathematical communities. From the methodological point of view, the following works were the most beneficial for the project: Aubin, Goldstein 2014; Duren, Askey, Merzbach 1988-1989; Goldstein, Gray, Ritter (eds.) 1996; Pier (ed.) 1994; Suzuki 2009; Vekerdi 1996.

The team relied also on their previous research work and publications, which were more or less related to the topic under preparation, for example Bečvář 2007; Bečvářová 2016; Domoradzki, Stawiska 2015a; 2015b; Duda 2014; Netuka 1995; Slavík 2007.

\section{Project team and its support}

At the beginning of the spring of 2017, we created an international team of experts who had collaborated on smaller research studies for many years and had met regularly at international conferences and local or national seminars. The team brought together active mathematicians, historians of mathematics, and historians of sciences from five countries. Martina Bečvářová (Czech Technical University, Prague, Czech Republic) became the team leader. Vojtech Bálint (Žilina, Slovakia), Jindřich Bečvář (Charles University, Prague, Czech Republic), Roman Duda (Wrocław, Poland), Stanisław Domoradzki (University of Rzeszów, Poland), Ivan Netuka (Charles University, Prague, Czech Republic), Antonín Slavík (Charles University, Prague, Czech Republic), Margaret StawiskaFriedland (Mathematical Reviews, American Mathematical Society, USA), Jiří Veselý (Charles University, Prague, Czech Republic) and Michael Zarichnyi (Ivan Franko National University of Lviv, Ukraine) were the team members.

The team members had long discussions about the sources to be studied and used, where they can be found, how to analyze them, how to write and where to publish the results, and what would be interesting for national and international readers. It was also difficult to set the main research goals and divide the research work into sub-stages.

The team also planned collaboration with mathematicians (among others, Stephen Gardiner), historians of mathematics (Menso Folkerts, Luigi Pepe, Karl-Heinz Schlote, Reinhard Siegmund-Schultze, Renate Tobies, etc.) as well as historians and archivists (Hana Kábová, Vlasta Měštánková, Eva Semotanová, Petr Svobodný, Jan Škoda, etc.). 
In the spring of 2017, the team leader together with the team members prepared the application for the competition announced by the Czech Science Foundation. At the end of the year 2017, the project proposal titled The impact of WWI on the Formation and Transformation of the Scientific Life of the Mathematical Community succeeded and received support for the years 2018-2020. The Czech Science Foundation is the only institution in the Czech Republic that provides public funding exclusively for basic research projects. ${ }^{3}$

The team members regularly met twice or three times a year in Prague, Poděbrady, or Kraków. They thoroughly coordinated their research and publishing activities, they discussed the content, style, and structure of their published outputs as well as their presentations at the conferences and the popularizations of the project. Thanks to the support, the team was able to expand and deepen their cooperation.

\section{Timeliness of the project}

The timing of the proposed project seemed to be optimal for the following reasons. On the one hand, almost 100 years had passed since the end of WWI, which made it possible to look at mathematical communities, mathematics, and their history from a broad historical perspective. On the other hand, several European historians (in particular, historians of mathematics) are now deeply interested in this topic and our project might represent a suitable platform for a successful international collaboration and exchange of ideas and opinions. We thought that the project could bring valuable results, long-standing professional contacts, and possibly to forthcoming joint research. Another aspect is that many older archival sources and materials had been digitalized andare available to scholars.

\section{The main purpose of the project}

The goal of the project was to obtain new results, gain valuable knowledge, fill in a gap in the existing literature, and analyze, summarize, describe, compare and comment on the achievements of the mathematical community, and on the role and scientific contribution of

${ }^{3}$ For more information on the activities of the foundation, see Czech Science Foundation 2020. 
mathematicians from Central and Eastern Europe to the development of their discipline.

After long discussions, we decided to write several specialized case studies describing a typical mathematical career in the interwar period. Special attention was paid to the situation at the newly established or reorganized higher education and research institutions in Czechoslovakia, Poland, Hungary, and Russia. We also wanted to show how the shape of the academic landscape and the development of science were strongly interwoven with the political situation and prevailing attitudes in society at the time.

Moreover, we analyzed and carefully documented some surprising phenomena specific to Central and Eastern Europe. For instance, many young mathematics students from the Czech lands had to interrupt their careers after having been recruited, whereas only a few Czech and German mathematicians and professors of mathematics actively participated in the war. They were "saved" because of their higher age, lack of Austro-Hungarian citizenship, and because they were considered experts of high importance for special war tasks (for instance, artillery calculations, meteorological measurements for the marines or air force, war research, ensuring communications, cryptography, war planning, and strategy preparations), or served as officers or teachers at secondary military schools. WWI and especially the relentless Polish struggle for independence brought a period of unprecedented growth to the Polish mathematical community in Lwów, Warsaw, and Kraków. Polish mathematics was at its peak and its results achieved world-wide fame and recognition. A remarkable fact was the boom among Hungarian scientists between the 1920s and 1930s, as well as the effort of Russian mathematicians to obtain German or American scholarships for their studies in western Europe or the USA. A phenomenon of great importance is the emancipation of women and their attempts to change their fate, their status in the society, and their position in the academia or research.

We recognized that the description of the history of mathematical communities had to be based on a deep expert analysis of the development of mathematics as well as mathematical ideas and reasoning. We also decided to bring original insights into the history of mathematics by investigating the origin, significance and implications of groundbreaking mathematical ideas and trends in interwar mathematics. 


\section{Conceptual and methodological approaches of the project}

The project was based on extensive research of review journals, databases, mathematical journals, and bibliographical sources in European archives and libraries. It was interdisciplinary and international in nature. Materials needed to be collected to analyze, evaluate, and comment on the influence of WWI on the development of modern mathematics from both national and international perspectives. To this end, we studied archival materials deposited in Czech, Slovak, German, Polish, Hungarian, Ukrainian, and Russian archives, which have not received enough attention until now.

The project was also based on existing extensive literature (journals and proceedings), where topics are treated frequently in a fragmentary style, often separately, from different professional, national, historical, and political perspectives, and on a variety of monographs dealing with the development of mathematical subdisciplines. We compared and confronted existing opinions and results, in many ways still incomplete, and refined and expanded them. Using case studies, we provided a new overview of the interwar development of the mathematical community, especially in Central Europe.

The project used primary mathematical sources, research monographs, and also textbooks published in the interwar period, as well as modern Internet databases of mathematical works, their abstracts and reviews, databases of historical literature on the development of Central Europe, databases of articles in the field of engineering, medicine, natural sciences, humanities, and social sciences (e.g. Jabrbuch über die Fortschritte der Mathematik, Mathematical Reviews, Zentralblatt für Mathematik, European Digital Mathematics Library). The project benefited also from national prosopographical databases of scientists, encyclopedic dictionaries, biographical and bibliographical papers on the life and work of prominent mathematicians.

\section{Project goals}

The main goal of the project was an in-depth analysis of the development of mathematical communities and scientific schools in Central and Eastern Europe in the interwar period on the background of the political, 
cultural, social, and scientific changes. After the preparation, we selected the general topics, problems, and questions for our investigation.

Firstly, we focused on the influence of WWI on the development of mathematical communities. We wanted to analyze the historical, political, social, and mathematical background to the interwar evolution of mathematical communities and schools, and to study the interwar rebirth of international collaboration, exchange of ideas, the advancement of mathematical knowledge in Central Europe, and their subsequent influence and relevance to the development of science.

We knew that WWI interrupted the routine life of many professional European communities and destroyed their activities and collaborations. We therefore tried to analyze the revival of mathematical communities, especially in Central and Eastern Europe, from a historical perspective and with an emphasis on the roots of modern scientific societies and the transfer of people and ideas. We made an effort to provide answers to the following issues:

a) the ways of rectification of the consequences of WWI (as staff casualties, damage to buildings, and destruction of libraries) in European countries;

b) the influence of the global changes in Europe (the emergence of new states, economic crisis, or nationalistic conflicts) on the establishment of new societies and universities;

c) the typical trends in the development of mathematical societies;

d) the causes of the establishment of mathematical centers and their role;

e) why, which and where new journals were established, and the typical motives for their topical categorization;

f) the relevance of the scholarships in Germany and the USA and local professional meetings to early-career mathematicians.

It was generally known and described, that WWI was a serious blow to international cooperation. The way to its recovery was one of the themes of our project. We placed a special emphasis on the discussion of German science losing its status significantly after 1918, and on the boycott and exclusion of German mathematicians, especially from the participation at the International Congress of Mathematicians (Toronto, 1924). The background of this serious decision (based on the principle of collective guilt) by the International Mathematical Union deserves deeper historical research. Implications for the further development 
of the mathematical community in Europe during the interwar period will be investigated. We planned to focus mainly on the following points:

a) the analysis of the wide spectrum of controversial opinions by great personalities of European and North American mathematics on the exclusion of German mathematicians;

b) the reaction of the German mathematical community and consequences of the exclusion for the next International Congress of Mathematicians;

c) the circumstances of how the Fields medals, considered to be one of the equivalents of Nobel Prizes for mathematics, were established;

d) the role of Czechoslovak mathematicians in international mathematical organizations (European affairs and the position of small countries).

Mathematicians in WWI and their role in the war research seems to be an interesting topic of our studies. We decided to pay special attention to the issue of war victims among mathematicians, and on recovery of mathematical life in war-affected countries. We mainly concentrated on:

a) the individual destinies of mathematicians during the war;

b) the renewal of the life of mathematical communities after 1918;

c) the tragic fate of the Czech mathematician František Velísek, some unknown facts from the life of Gerhard Hermann Waldemar Kowalewski, Saly Ruth Struik, Lipót Fejér, Ferenc Kárteszi, Rátz László, Pál Erdős, Otto Varga, Otto Eduard Neugebauer;

d) the participation of mathematicians in the war research during WWI.

The development of national mathematical communities and scientific schools in Central and Eastern Europe became the core of our research. We prepared some special and typical case studies, which analyzed the transformations of scientific life in the interwar period. The impact of some historical phenomena was described in a broader historical context (social phenomena, the reconstruction and development of international cooperation, the effects of religious persecution, rising anti-Semitism and political purges, the process of emancipation of women in science, etc.). Our research focused on historical aspects but brought also original insights into the history of mathematics because the analysis was devoted to the origin, significance, and implications 
of groundbreaking mathematical ideas on the trends in mathematics. Due to the composition of the team, we chose the Czechoslovak, Polish, Hungarian, German, and Russian mathematical communities.

Since a large part of the team was from the Czech Republic, we decided to analyze in detail the history of the mathematical community in Czechoslovakia in the interwar period. There were many causes for this decision. After the creation of the Czechoslovak Republic (1918), the Czech mathematical community developed rapidly. Despite numerous problems, the German scientific and cultural milieu was not abolished in Czechoslovakia, unlike other non-German parts of the former Austro-Hungarian Empire. After WWI, Prague attracted many foreign students (from Germany, Austria, Poland, Ukraine, Latvia, Russia, etc.) because of favorable living conditions, democratic and multicultural atmosphere, religious and racial tolerance, and many distinguished professors. In the Czech lands, the mathematical communities had a good and long-term tradition and ample activities thanks to the Union of Czech Mathematicians and Physicists (founded in 1862) and the German Mathematical Circle in Prague (founded in 1913/1914), which operated even during WWI. We selected the following points:

a) the role of the Union of Czech Mathematicians and Physicists in the creation of new Czech mathematical journals, book series, and textbooks;

b) the analysis of a new kind of international collaboration (personal professional contacts of some Czech mathematicians with Italian, Russian, and German mathematicians);

c) the position of Czechoslovak mathematicians in the world research trends and activities;

d) the analysis of several specific Czechoslovak paradigms (long discussions concerning the establishment of Masaryk University in Brno, education policy in Slovakia, the decline of the so-called Czech geometrical school, the existence of two national scientific communities).

Because the team consisted of several experts from Poland, it was perfectly natural to try to analyze the transformation of the Polish mathematical community in the interwar period. The modern Polish mathematical community was born after WWI and during a very short time, it became one of the leading and most active communities, not only in Europe. As a result of the war, Poland regained independence 
after 123 years of occupation and subsequently reorganized academic life, and rebuilt the state institutions in Lwów, Warsaw, and Kraków. The existing literature is focused on the situation in the first two cities, while the achievements of Kraków are less known, but also significant. We mainly concentrated on:

a) the analysis of the cultural and historical background of Polish mathematics after WWI;

b) the analysis of the roots of the revitalization of Lwów's academic life after WWI and the foundation of the famous and successful Lwów mathematical school;

c) the analysis of the role of young, talented, and spirited mathematicians in the process of transformation of the University in Warsaw and its mathematical community (An unprecedented phenomenon of collaboration between mathematicians and logicians will be also discussed.);

d) the analysis of the position of the Jagiellonian University in Kraków and its mathematical community.

Several members of the team had long dealt with the issues of the German mathematical community, German pure and applied mathematics, and the relations of German mathematicians to other mathematical communities. We therefore decided to analyze the scientific contacts and cooperation of Germany and the USSR between the wars. The roots of cooperation between Europe and Russia in the field of mathematical sciences can be traced back a long time before the establishment of the USSR in 1922. The USSR inherited advanced contacts of leading scientists with centers in Paris, Berlin, Göttingen, and others. Russia was a member of the Triple Entente, but after the October Revolution, the RSFSR and Central Powers signed ceasefire agreements, which were followed by the German offensive and finally by the Brest-Litovsk agreement. Both Germany and Soviet Russia felt isolated after the changes caused by WWI. This led to the Treaty of Rapallo signed in 1922, which established the cooperation of both states in different fields, including research in mathematics. Numerous Soviet scientists traveled to Germany and other European countries, and some German mathematicians lectured in the USSR. These contacts were destroyed when the Nazis came to power in Germany. Just before WWII, both states were controlled by a single party which among other things changed the life of scientists in the whole of Europe. The study concentrated on: 
a) the impact of anti-Semitism on the changes of science;

b) the destruction of mathematical research centers;

c) universities and academies in the struggle with terror;

d) the life of the mathematical community in the dictatorship era.

The mathematical community in Hungary in the interwar period was for many reasons a fascinating topic because before 1850 there were only two prominent Hungarian mathematicians - Bolyai Farkas and his son János. However, towards the end of the $19^{\text {th }}$ and in the first decades of the $20^{\text {th }}$ century, a larger group of naturalists emerged, which consisted mainly of outstanding teachers of physics, mathematics, and chemistry. Together they formed a particularly strong group of so-called Martians. Members were not only physicists but also chemists, mechanical engineers as well as several mathematicians, who made a significant contribution not only to the development of existing disciplines but also to the establishment of a separate sector of mathematical research. We analyzed this process in a historical context and the results were presented in a form understandable to non-specialists. In terms of mathematics, we focused on number theory, graph theory, and socalled discrete geometry.

We also found several special topics that were significant for the interwar period - women's university education and the international transfer of knowledge in connection with the mobility of researchers. We therefore decided to write special case studies on these topics.

WWI opened the door to a new phenomenon - the growth in the number of women studying at universities, and the growth of their significance in the social and scientific environment. Our investigation was devoted to the largely unknown and mostly forgotten history of female PhD candidates in mathematics in the period 1882-1945 at the German University in Prague throughout its existence (1882-1945), and at the Czech University in Prague (1882-1920), later transformed to Charles University (1920-present). We determined the following research problem areas:

a) the analysis of the background to women's university education in the Czech lands;

b) the outline of the rules and regulations in the process of obtaining doctoral degrees;

c) the statistical overview of all $\mathrm{PhD}$ degrees in mathematics awarded at both universities in Prague; 
d) the survey of successful and unsuccessful female doctoral procedures;

e) the analysis of the social and historical background of their life stories, professional activities, and fates of their families and relatives.

After the creation of Czechoslovakia, the most talented Czech mathematicians went abroad, thanks to government scholarships and funding. They traveled mainly to Germany, France, or Italy. Among the most notable archival documents from this period, located in the Archive of the Academy of Sciences of the Czech Republic, are fourteen notebooks with notes written by Vojtěch Jarník, the future prominent Czech mathematician, during his studies in Göttingen. The notebooks contain his notes from the lectures delivered by Amalie Emmy Noether, Karl Grandjot, Pavel Sergeyevich Aleksandrov, and Bartel Leendert van der Waerden. Jarník's notebooks were discovered by Jindřich Bečvár in 2004 when he was preparing an extensive monograph on the life and work of Vladimír Kořinek, a Czech algebraist of the 20th century. We reproduced, commented on, and analyzed unique archival materials five of Jarník's mathematical notebooks (more than 300 pages) which he wrote in the academic year 1927/1928 and which contain records of the lectures delivered by van der Waerden during the courses entitled Allgemeine Idealtheorie and Algebraische Zablen. We mainly concentrated on:

a) the comparison of the content, structure, mathematical concept, and style of mathematical interpretation of van der Waerden's lectures with his famous textbooks Modern Algebra I (1930) and Modern Algebra II (1931), which strongly influenced generations of mathematicians;

b) the description of how Waerden's lectures reflected the state-ofthe-art and thinking in modern algebra following 1928;

c) the analysis of the role of the distinguished mathematician in the development of algebra;

d) the transfer of his new ideas from Germany across Europe;

e) the reasons why and how Waerden's concepts influenced the style of algebra teaching.

The Great War heavily affected academic institutions. In European countries, many talented researchers were killed in action; scientific activities were significantly frozen and were resumed only in the years after the end of the war. However, this inhibition turned out to be 
a catalyst for the birth of a new generation of mathematicians, for the emergence of new ideas and theories, and for the surprising creation of new and outstanding scientific schools (which occurred in Poland and Hungary, for instance). These phenomena are not sufficiently reflected in the existing research literature. One of the goals of the proposal is to offer an analysis of the most important aspects from a historical perspective and to show the main themes through case studies devoted to selected mathematical disciplines. Some of them are (to a certain extent) covered in several studies, for instance, topology, logic, linear algebra, topology, probability, analysis, number theory, functional analysis, product integration, or mathematical analysis (but discussed in an encyclopedic style only). Our study could not miss the development of mathematics as a science. From the beginning, however, we were aware that the team could not describe the development of interwar mathematics. Consequently, our attention was primarily focused on those fields where a deeper analysis encompassing a wider historical context is not available.

Firstly, we decided on the case of modern algebra because between WWI and WWII, so-called modern algebra was born out of the research activities of the German mathematicians Emil Artin, Amalie Emmy Noether, and Bartel Leendert van der Waerden. We tried to capture the most important results and trends in modern algebra in the period between the wars. The following problems were discussed:

a) the development of abstract algebraic structures, which started a hundred years ago thanks to the work of Évariste Galois;

b) when, why, how, and by whom the axiomatization of algebra was created;

c) when the new important algebraic structures (for example groups, rings, unions, representation, category theory) became standard parts of university lectures or textbooks;

d) when and how the new structures appeared in physics and why they were applied,

e) the significance of Waerden's two-part monograph Modern Algebra from 1930 and 1931;

f) the impact of Waerden's book on the work of French mathematicians who published under the pen name Nicolas Bourbaki.

Secondly, we selected the case of potential theory because it witnessed a remarkable boom during the interwar period. In fact, until 
around 1850, potential theory had been a chapter of physics. It later contributed significantly to the solution of various fundamental problems of mathematical physics (boundary value problems, integral equations, calculus of variation, for instance), and finally in the 20th century became an autonomous, entirely mathematical discipline representing a crossroads of many mathematical fields. Potential theory served as a source of motivation for several newly emerging subjects, such as measure theory, integration theory, or functional analysis. During the interwar period, a kind of inverse process occurred: the methods of modern mathematics enriched potential theory in an unexpected way. In this project, the primary focus was given exactly to this process of historical transformation, and conclusions of a general nature will be drawn. The driving forces for the development of mathematical thinking were also emphasized. We also focused on the interplay between the categories of concrete/abstract as well as theoretic/applied. Of course, the study of the interwar period has to come from material of a concrete nature. One cannot entirely avoid mentioning a few technical concepts not necessarily common for non-specialists (potentials, integral of energy, generalized Dirichlet problem, capacity, etc.). However, we intended by no means to present a dry mathematical exposition. On the contrary, the leading direction of our investigations lay in a historical analysis of concepts, important notions, and evolutionary trends showing general features not necessarily related to the mathematical substance of the field in question. The case study aimed at the clarification of questions concerning:

a) the historical insight into the transformation of a discipline originally belonging to physics into a purely mathematical subject;

b) the interplay and intertwining of ideas from various disciplines and the role of leading personalities in the determination of the main themes of subject development and the creation of the expert community;

c) the curious delay in the emergence of probabilistic potential theory as well as the role of errors, frequently fruitful, in mathematical knowledge.

As the third mathematical topic, we chose the case of combinatorics. This case study focused on combinatorics and discrete mathematics in general. In the interwar period, combinatorics became an increasingly important mathematical discipline with various distinct and fairly specialized subdisciplines. This period witnessed the birth of the 
Ramsey theory (that is, the search for order in large random structures), the development of graph theory (including major progress towards the proof of the four-color theorem), the emergence of combinatorial set theory, the fundamental results on integer partitions, or the renewal of interest in Latin squares, block designs and their applications in the design of experiments. We relied on the basic sources in the history of combinatorics. However, these sources cover much longer periods in the history of combinatorics and graph theory and therefore do not include sufficient details on the interwar period. Moreover, the first reference is written primarily for specialists in combinatorics; we planned to summarize the history in a text accessible to a wider audience.

We decided on our results stemming from the project solution published in papers and monographs. We hope that they brought new original insights into mathematics sciences from a historical perspective. The outcome of our research was presented at international conferences and seminars.

\section{The results of the project}

Thanks to the research in the archives, libraries, collections, bibliographical works, review databases, mathematical journals, monographs and textbooks, periodical meetings and seminars of team members with discussions on literature, archive sources we obtained provided plenty material for our publication outputs.

The most important results include five monographs written in Czech and English and published in the various Czech printing houses as well as in the international publishing house.

The first one named Dopady proni svètové války na mezinárodní spolupráci matematik. $\dot{u}$ [The impact of the First World War on the international cooperation of mathematicians] was written in Czech by Martina Bečvářová and Ivan Netuka. It was published by České vysoké učení technické v Praze, Česká technika - nakladatelství ČVUT in 2019 (see Bečváŕová, Netuka 2019). The monograph deals with the origins and transformations of the international cooperation of mathematicians in the period from the late 1880s to the beginning of WWII. Individual chapters illustrate how war conflicts, political decisions, social climate, economic instability, and personal conflicts negatively influenced the 
life of the scientific community and also affected its professional development. The text focuses primarily on the five pre-war international congresses of mathematicians $(1897,1900,1904,1908$, and 1912) and five interwar international congresses of mathematicians $(1920,1924,1928$, 1932, and 1936). It describes the origination of the first international organization, i.e. the International Union of Mathematicians (founded in 1919), which has since influenced the development of mathematics and the mathematical community. The significant and wide-ranging activities of the International Commission on Mathematics Education (created in 1908) are discussed together with its role in the reforms of teaching mathematics in European countries during the first third of the $20^{\text {th }}$ century. The historical circumstances of the creation of the first international mathematical prize, the Fields Medal, are also analyzed;the medal, which was founded in 1932 was only first awarded in 1936 after complicated international negotiations. The text of the monograph is supplemented with pictures that provide a deeper and better understanding of the studied subject.

The monograph is written to be attractive to mathematicians, science historians, teachers, and students. The authors aimed to make the presented topics accessible to a wide range of Czech readers. ${ }^{4}$

The second monograph is titled Doktorky matematiky na univerzitách $v$ Praze 1900-1945 [Female Doctors of Mathematics at the Universities of Prague 1900-1945] was written in Czech by Martina Bečvářová. It was published by the publishing house Univerzita Karlova v Praze, Nakladatelství Karolinum in 2019 (see Bečvářová 2019a). The book is devoted to the largely unknown and mostly forgotten history of female $\mathrm{PhD}$ candidates in mathematics in the period 1882-1945 at the German University in Prague and the Czech University in Prague (i.e. Charles University). The following topics are described and presented: the background to women's university education in the Czech lands, the rules and regulations in the process of obtaining doctoral degrees, a statistical overview of all $\mathrm{PhD}$ degrees in mathematics awarded at both universities in Prague from 1882 to 1945, a survey of successful and unsuccessful female doctoral procedures ${ }^{5}$, an analysis of the social and historical

${ }^{4}$ For detailed review, see for example Slavík 2019b.

5 These twelve women - three of German and nine of Czech nationality - were the following: Saly Ramler, Hilda Falk, Josefine Mayer (neé Keller), Marie Fabiánová, 
background of their life stories, professional activities, and fates of their families and relatives. Various materials were gathered. Interestingly, fewer sources were found on the studies of the German candidates, but considerably more sources allowing a deeper analysis of their careers and lives. This is because the official materials of German schools and institutions were, in the past, more liable to being discarded and destroyed owing to the political development than the materials of the Czech ones. On the other hand, the personal materials of the German candidates in the National Archives of the Czech Republic were better preserved and accessible because they were not classified as the so-called "living", respectively "unprocessed" or "inaccessible" sources. The lives of the Czech doctoral candidates in mathematics could be reconstructed only partially, thanks to the willingness of their direct relatives. Searching for them was demanding and resembled detective work.

The monograph is the first comprehensive and extensive book analyzing the difficult path of women in Czechoslovakia to studying mathematics at university and their role in mathematics, which had originally been a purely male profession. Although almost none of them devoted themselves to mathematics after obtaining the doctorate (for various reasons), they proved to be able to compete with men, provided they had the motivation and courage to do this: at the time the public regarded female mathematicians with distrust. The book could appeal to readers interested in gender studies, sociology, history of science, history of education as well as mathematics and its history. ${ }^{6}$

The third monograph is titled Jarnik's Notes of the Lecture Course Allgemeine Idealtheorie by B. L. van der Waerden (Göttinten 1927/1928). It was written by Jindřich Bečvář and Martina Bečvářová (see Bečvář, Bečváŕová 2020a). It was published in the "Series History of Mathematics" as volume 64 by the publishing house Matfyzpress in Prague in 2020. The book includes the reproductions, analyses, and comments on the unique archival materials - Jarník's mathematical notebooks, written in the academic year 1927/1928 in Göttingen and containing records of the lectures delivered by van der Waerden during the course entitled Allgemeine Idealtheorie. The first chapter gives a short description of van

Miluše Jašková, Helena Navrátilová, Jarmila Šimerková, Věra Čechová, Ludmila Illingerová, Věra Kofránková, Jiřina Frantíková, and Libuše Kučerová.

${ }^{6}$ For more information on the book, see for example its review: Trkovská 2019. 


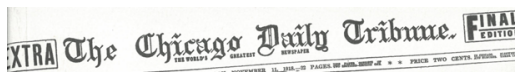

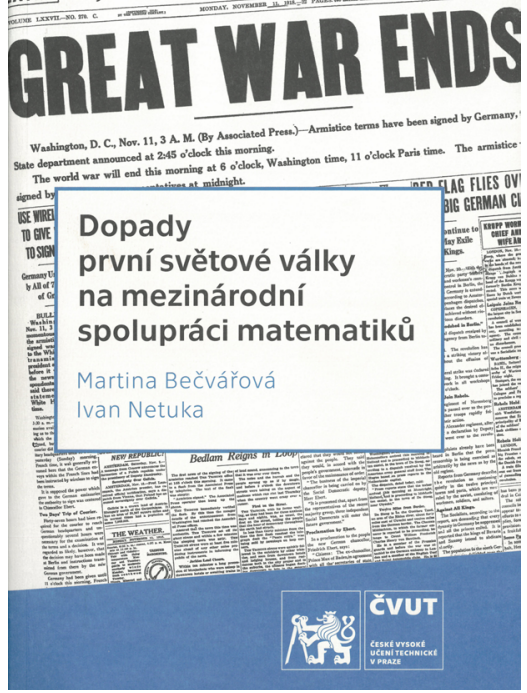

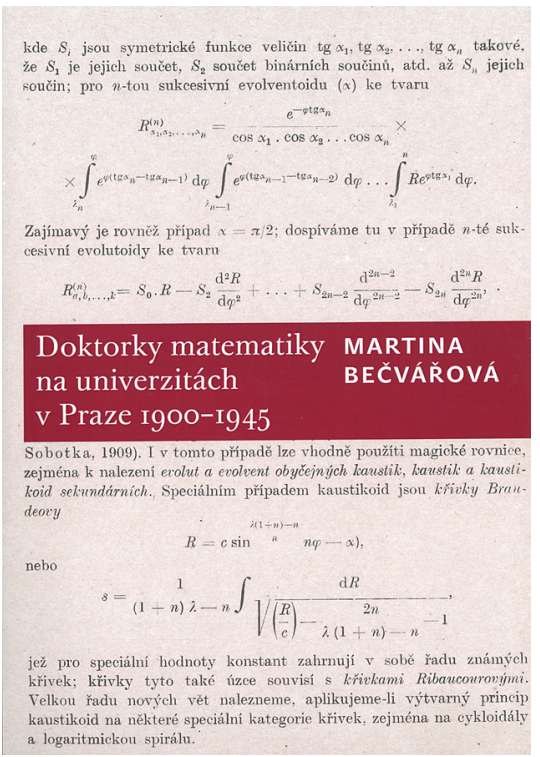

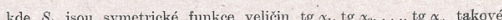
ončin: pro $n$-ou sukcesirni evolventoidu (a) ke tvarı

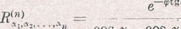

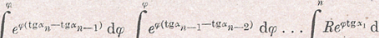

Doktorky matematiky MARTINA

na univerzitách

BEČVÁŘ OVÁ

\section{v Praze igoo-1945} a logaritmickou spirál

Fig. 1. The title pages of the books published thanks to the project. Authors: Martina Bečvářová and Ivan Netuka, 2019, resp. Martina Bečvářová, 2019.7

der Waerden's life and scientific results in mathematics and the history of mathematics as well as pedagogical activities in Amsterdam, Göttingen, Leipzig, and Zurich. The second chapter deals with the founding of the University in Göttingen and the development of mathematical studies and research there. The atmosphere in the mathematical center in the 1920s and 1930s is brought to life with the help of some passages chosen from the recollections of some outstanding mathematicians who lectured or studied there. The third chapter is devoted to Jarník's life and work in Prague and mainly to his studies at the University in Göttingen. The fourth chapter provides a general account of Jarník's fourteen notebooks and a short description of his sixth and seventh notebook, which contain van der Waerden's lectures titled Allgemeine Idealtheorie. The fifth chapter analyzes the most famous textbooks on algebra which were written in German, French, English, and Italian from the end of the 19th century until the beginning of the 1930s, i.e. before the birth of van der Waerden's Modern Algebra. The contents, structure, authors

7 See Bečvářová, Netuka 2019; Bečvářová 2019a. 
of interpretations and influence on the development of algebra are recalled. The final appendix summarizes the most important information about the origins of van der Waerden's Moderne Algebra and the literature recommended by the author to study. It shows how the content of van der Waerden's textbook had changed over nearly four decades. At the end of the appendix, an overview of all editions of this textbook, available in European and American libraries, is included with links to reviews published in references and mathematical journals. These chapters allow the reader to compare the content, organization, and interpretation of algebra in van der Waerden's lecture delivered in 1927/1928 with the content, organization, and interpretation in the first edition of his twopart textbook Moderne Algebra $(1930,1931)$, in the second edition (1937, 1940) to the seventh/fifth edition $(1966,1967)$. Illustrations and copies from Jarník's notebooks and some archival materials and documents can be found at the end of the book.

The authors traced the origin of the results to place the material in a historical context. Their several quotations and bibliographical comments illustrate the fact that the first quarter of the 20th century was a fascinating period for the development of mathematics. Van der Waerden's course has several remarkable features. It reflects the stateof-the-art in important parts of these fields of mathematics in 1928. The course is very modern in the sense that practically all results presented were less than thirty years old, the majority were less than ten years old, and some were not yet published. It centres around several excellent results established by Emil Artin, Amalie Emmy Noether, Bartel Leendert van der Waerden as well as by his collaborators and colleagues and includes principal results and concepts of modern algebra that have become standard facts presented today in basic university courses for mathematicians. It uses mathematical language and a style of exposition of results and their proofs that is similar to the contemporary way of presenting mathematics. In summary, the course was delivered by a distinguished expert whose impact on contemporary mathematics is felt till today. The book could appeal to mathematicians as well as historians of sciences and people interested in mathematics and its history.

The fourth book named Matematický svèt mez̧i valkami [The mathematical world between wars] was written in Czech as a collective monograph under the editorial guidance of Jindřich Bečvář and Martina 
Bečvářová (see Bečváŕ, Bečvářová 2020b). It was published as the $65^{\text {th }}$ volume of the "Series History of Mathematics" by the publishing house České vysoké učení technické v Praze in 2020. The monograph is based on a long-term and intensive study of the history of mathematics and mathematical communities. In a broader cultural and historical context, it discusses the effects of WWI on the professional life of outstanding mathematicians (Andrey Nikolaevich Kolmogorov, Max Wilhelm Dehn) as well as European mathematical communities (the Prague German Mathematical Community and its professional association Mathematische Kränzchen, Luzitania and its position in the Russian interwar mathematical community, the Czech/Czechoslovak mathematical community and its relation to the congresses of naturalists and physicians and the popularization of mathematics). It also focuses on the nature and impact of selected mathematical ideas on the development of certain areas of mathematics and mathematical physics (matrix theory and its use in quantum mechanics, matroid theory and its relation to other mathematical disciplines, the role of sweeping in potential theory, axiomatic probability theory and the Czech contribution to its development, the solution of Hilbert's third problem and historical reminiscence). The impact of war events and social changes on the development of mathematics teaching is also discussed, especially with regard to the education of talents and popularization of mathematics (reform of mathematics teaching in the interwar and post-war Soviet Union, almost a century-old history of the popular Czechoslovak magazine Rozbledy matematicko-fyzikální [The mathematical and natural horizons]). The book could appeal to a wide range of readers ranging from mathematicians and historians of mathematics, through historians of science to teachers and students.

The main result of the project is a book in press; it will be published in June 2021 by the famous publishing house World Scientific. Its title is The Development of Mathematics between the World Wars. Case Studies, Examples and Analysis (see Bečvárová (ed.) 2021). The book traces the transformation of scientific life within mathematical communities during the interwar period in Central and Eastern Europe, specifically in Germany, Russia, Poland, Hungary, and Czechoslovakia. The final four chapters are not restricted to Central and Eastern Europe and deal with the development of mathematics between World War I and World War II. After describing the general state of mathematics at the 
end of the $19^{\text {th }}$ century and the first third of the $20^{\text {th }}$ century, three case studies dealing with selected mathematical disciplines are presented (set theory, potential theory, and combinatorics). ${ }^{8}$

Its content can be briefly characterized by the names of individual chapters: "German Mathematics Between Two World Wars", "Russian Mathematics and Its Relation to German Mathematics (1914-1940)", "Roots of Modern Polish Mathematics (1815-1915)", "The Position of the Jagiellonian University and Its Mathematical Community Before and After WWI", "Transformation of the Warsaw Mathematical Community in the Aftermath of WWI", "Formation and Activity of the Lwów School of Mathematics", "Impact of World War I on the Mathematical Community in Hungary", "Mathematical Community in Czechoslovakia Between World Wars", "The End of the $19^{\text {th }}$ Century and the First Third of the $20^{\text {th }}$ Century", "Set Theory A Vehicle to Modern Mathematics in Poland", "Transformation of Mathematics Between World Wars: the Case of Potential Theory"

8 The monograph on a closely related topic appeared recently. See Mazliak,Tazzioli 2021. The book is the main result of the international meeting organized in Marseilles in November 2018. Its chapters are devoted to the aftermath of the Great War for mathematical communities. Its content can be briefly characterized by the names of individual chapters: "William Henry Young, an Unconventional President of the International Mathematical Union” (Guillermo P. Curbera), "The Unione Matematica Italiana and Its Bollettino, 1922-1928. National and International Aspects" (Livia Giacardi et al.), "L'Enseignement Mathématique and Its Internationalist Ambitions During the Turmoil of WWI and the 1920s" (Hélène Gispert), Mathematics and Logic in Polish Encyclopedias Published During the Interwar Period" (Roman Murawski), "From the War Against Errors to Mathematics After the War: Public Discourses on a New Mathematical Dictionary" (Laura E. Turner), "International Geodesy in the Post-war Period, as Seen by the French Bureau des Longitudes (1917-1922)" (Martina Schiavon), "The First Mathematically Serious German School of Applied Mathematics"? (Reinhard Siegmund-Schultze), "The Mathematics of Nonlinear Oscillations in the 1920s: A Decade of Trials and Convergence? Examples of the Work of Nicolai Minorsky" (Loïc Petitgirard), "From Fundamenta Mathematicae to Studia Mathematica: The Renaissance of Polish mathematics in light of Banach's publications 1919-1940" (Frédéric Jaëck), "Following Béla von Kerékjártó. The Journeys of a Hungarian Mathematician in the Post-war World" (Alicia Filipiak), "Under the Protection of Alien Wings. Russian Emigrant Mathematiciancs in Interwar France: A General Picture and Two Case Studies of Ervand Kogbetliantz and Vladimir Kosticyn" (Laurent Mazliak et al.). It is seen that the book analyzes the other topics connected with revitalization of mathematics and mathematical communities after WWI. 
and "Transformation of Mathematics Between World Wars: the Case of Combinatorics". Most chapters are accessible to a general readership, but the mathematical chapters are accessible to graduate students and researchers in mathematics. ${ }^{?}$
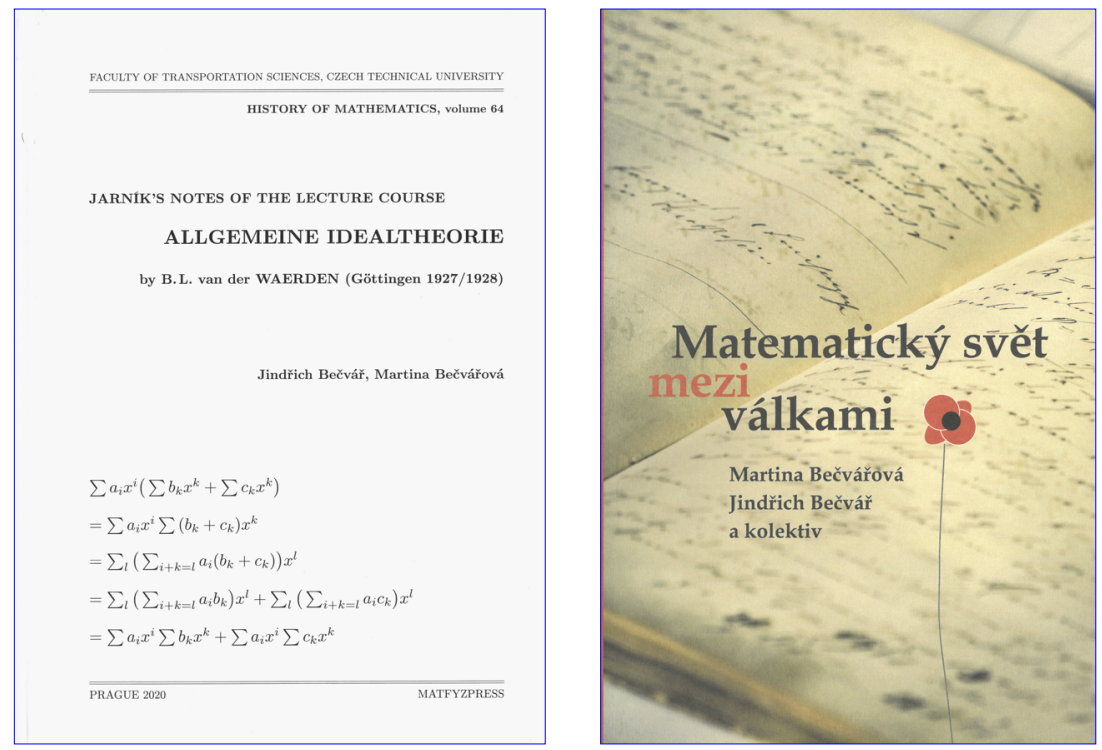

Fig. 2. The title pages of the books published thanks to the project. Authors: Jindrich Bečvář and Martina Bečvářová, 2020, resp. Jindřich Bečvář and Martina Bečvářová, 2020. ${ }^{10}$

The Polish part of the team (S. Domoradzki, M. Stawiska-Friedland, M. Zarichnyi) presented the part of their most important research at the invited lecture titled "On the Importance of the Scottish Book. On the $85^{\text {th }}$ Anniversary of its Foundation" at the meeting of the Commission on the History of Science, the Polish Academy of Arts and Sciences. At the lecture, they described the history of some problems, their solutions, and generalizations and showed that the Scottish Book had a great and continuing influence on the development of modern mathematics. They focused on the famous Schauder fixed point theorem and Banach's problem on homeomorphism of the spaces of type B. They demonstrated that the new mathematical areas initiated by the

${ }^{9}$ For more information, see World Science 2021.

${ }^{10}$ See Bečvár̆, Bečvářová 2020a; 2020b. 
Scottish Book include the theory of infinite and topological games and the theory of random graphs. ${ }^{11}$

Other significant results include two extensive chapters published in the books produced by the printing houses in the Czech Republic and Switzerland.

The first chapter was written by Jindřich Bečvár and Martina Bečvářová in 2019. Its name is "Matematika v období 1918 až 1950" [Mathematics in the period from 1918 to 1950] and it focuses on the fruitful development of Czech and German mathematics, mathematical schools and societies, and mathematics teaching in Czechoslovakia in the first half of the $20^{\text {th }}$ century. The chapter is a part of the extensive historical compendium describing the development of selected natural sciences in the Czech lands from the $14^{\text {th }}$ century until today. ${ }^{12}$

The second chapter was written by Martina Bečvářová and it was published under the title "Women and Mathematics at the Universities in Prague" (see Bečváŕová 2020). The chapter analyzes the study of the first twelve women-mathematicians at both Prague universities in a broad cultural, historical and political context. ${ }^{13}$

The team presented the results of their three-year research also in a number of articles published in the impacted, resp. peer-reviewed international and national journals. The publication of three articles in prestigious magazines with high impact scores can be considered a significant success. These articles were: M. Bečvářová: "Saly Ruth Struik, 1894-1993" (2018), A. Slavík: "Unbiased Version of Hall's Marriage Theorem in Matrix Form" (2019a), and I. Netuka: "Lebesgue's Criticism of Carl Neumann's Method in Potential Theory" (2020).

The first article is a study of the life events of Saly Ruth Struik, i.e. the first woman of German nationality who obtained her doctorate in mathematics at the German University in Prague. It is based on deep archival research in the Czech Republic.

The second article inspired by an old result by Georg Frobenius, shows that the unbiased version of Hall's marriage theorem is more

${ }^{11}$ For the text of the lecture, see Domoradzki, Stawiska, Zarichnyi 2021.

12 See Bečvár̆, Bečvářová 2019. For the detailed reviews, see Tesařík 2020 or Janout 2019 .

${ }^{13}$ For more information on the book which explores the origins and growth of women's role in the mathematical community, see Springer 2020. 
transparent when reformulated in the language of matrices. At the same time, it proves that in this way, one can obtain a more general statement applicable to bipartite graphs whose parts need not have the same size.

The third article contains an extensive historical-mathematical analysis of the development of Neumann's method in potential theory. It shows that in the 1870s, Carl Neumann proposed the so-called method of the arithmetic mean for solving the Dirichlet problem on convex domains. Neumann's approach was considered at the time to be a reliable existence proof, following Weierstrass's criticism of the Dirichlet principle. However, in 1937, H. Lebesgue pointed out a serious gap in Neumann's proof. Curiously, the erroneous argument once again involved confusion between the notions of infimum and minimum. The main core of this paper is to show that Lebesgue's sharp criticism of Neumann's proof was only partially justified.

Two special studies on the history of mathematics were published for Czech readers in the Czech journal Pokroky matematiky, fyziky a astronomie [Advances in mathematics, physics, and astronomy].

The first one titled "Cesta k pojmu kompaktního operátoru" JJourney to the concept of a compact operator] (2018) was written by Ivan Netuka. The article is devoted to the genesis of the concept of a compact operator. It shows the way of its creation from physics problems to their mathematical formulation using integral equations, through the boundary value problems of potential theory, through efforts to solve infinite systems of linear equations. It illustrates the idea of the prediction from finite to infinite, from discrete to continuous. It shows why and how mathematics arrived at functions of infinitely many variables, at spaces of functions and more generally, at infinite dimensions and fundamental mathematical concepts of mathematical analysis.

The second one titled "Hallova věta, její aplikace a historie" [Hall's marriage theorem, its applications, and history] (2018a) was written by Antonín Slavík. The text presents some classical and lesser-known applications of Hall's theorem, which belong to the basic pillars of combinatorics. The early history of the theorem and related statements are described.

Two articles on the activities of the international community of mathematicians in the interwar period were also written for Czech readers. 
The first article titled "Cesta ke vzniku Fieldsovy medaile" [Tracing the origins of the Fields Medal] (2018) was prepared by Martina Bečvářová and Ivan Netuka and it was published in the Czech journal Pokroky matematiky, fyziky a astronomie. The article describes in detail the historical circumstances of the first international mathematical awards, the so-called the Fields Medal (officially the International Medal for Outstanding Discoveries in Mathematics), which was established in 1932 after difficult negotiations and was first awarded in 1936. Based on archival sources, the authors comment on rumors that the absence of the Nobel Prize in mathematics is the result of problematic personal relationships between A. Nobel and the Swedish mathematician G. Mittag-Leffler. They also deal with the often-discussed issue of the age limit for the winners of the Fields Medal and the circumstances of the award being named after Fields, contrary to his express wish.

The second article titled "Zrod Mezinárodní komise pro vzdělávání matematice a její aktivity v letech 1908-1939" [The birth of the International Commission for Mathematics Education and its activities in 1908-1939] was written by Martina Bečvářová. It was published in the Slovak journal Obzory matematiky, fyziky a informatiky [The horizons of mathematics, physics, and computer science] in 2018 (see Bečvářová 2018b). Based on historical documents, the article analyzes the birth, development, and significance of the International Commission on the Teaching of Mathematics. Its most important activities from 1908 until 1939 and their impacts on the teaching of mathematics not only in the interwar period are described.

The Polish part of the team prepared three long articles on the history of the Polish mathematical community: Stanisław Domoradzki and Margaret Stawiska: "Polish Mathematicians and Mathematics. In World War I. Part I: Galicia (Austro-Hungarian Empire)" (2018); "Polish Mathematicians and Mathematics in World War I. Part II: Russian Empire" (ㅁ19), and Roman Duda: "One Hundred Years of the Polish Mathematical Society" (2018). They were written in English and are thus accessible to a wide readership. They were published in prestigious journals the Studia Historiae Scientiarum, realeased by the Polish Academy of Arts and Sciences, and the Antiquitates Mathematicae, released by the Polish Mathematical Society.

The articles by Stanisław Domoradzki and Margaret Stawiska present diverse experiences of Polish mathematicians (in a broad sense) who 
during World War I fought for the freedom of their homeland or conducted their research and teaching in difficult wartime circumstances. They discuss not only individual fates, but also organizational efforts of many kinds (teaching at the academic level outside traditional institutions, Polish scientific societies, publishing activities) to illustrate the formation of the modern Polish mathematical community. It is very important that the articles were published in the famous Polish journal Studia Historiae Scientiarum which is focused on the general history of science and its relationships with other domains of culture. It made the results of the project accessible to a wide range of readers.

The paper by Roman Duda deals with the history of Polish mathematical societies since 1917, when the Mathematical Society in Lwów was founded, until today. Firstly, it recalls that in the second half of the $19^{\text {th }}$ century first national mathematical societies appeared in Russia, France, the United Kingdom, Italy, the United States, and Germany. But in Poland, then partitioned by neighboring powers (Russia, Prussia, Austria), whose policy was to suppress Polish national development, this was not possible. An attempt was made abroad in the form of the Society of Exact Sciences in Paris, which functioned in 1870-1882. The situation was changed by the outbreak of World War I and the subsequent fall of all three partitioning powers. The Polish Mathematical Society was founded by its constituent assembly on April 2, 1919. The article describes the most important facts from the society's history: its foundation, beginnings, scientific activities, editorial activities; congresses of Polish mathematicians, international collaborations, international meetings in Poland; crisis and catastrophe of WWII, revival time after WWII, reforms under the communist regime, and marginalization of the Polish Mathematical Society; mathematical prizes and competitions, emigration of some mathematicians, post-communist revival, etc.).

The Slovak part of the team was made up of only one member. Thanks to his perfect knowledge of the Hungarian language, he was able to focus on the history of the Hungarian mathematical community. The project thus gained a unique opportunity to analyze the development of Hungarian mathematical research in the interwar period based on original Hungarian archival documents.

Thanks to the collaboration with the Polish part of the team, Vojtech Bálint published the article titled "Hungarian Mathematics Development 
Stimuli" in the journal Antiquitates Mathematicae in 2020 (see Bálint 2020a). The article shows that the KöMaL high school journal was one of the most significant factors in the development of Hungarian mathematics. It also demonstrates that the understanding of the importance of education by the Hungarian nobility, the Austro-Hungarian Compromise, and Mintagimnázium [Model high school] all played a key role.

Vojtech Bálint also wrote four articles in Slovak. The first three were published in the Slovak journal Obzory matematiky, fyziky a informatiky in 2019 and 2020, the last one was published in the Czech journal Pokroky matematiky, fyziky a astronomie in 2020. The articles "Lipót Fejér (1880-1959), Ferenc Kárteszi, Rátz László - učitel' géniov” [Rátz László teacher of geniuses], resp. "Pál Erdős trochu inak" [Pál Erdős - a little differently], as evident from their names, deal with the lives, mathematical and pedagogical works of well- and less-known mathematicians of Hungarian nationality, many of whom have influenced the development of mathematics teaching in Hungary and especially in Slovakia (see Bálint 2019; 2020b; 2020c; 2020d).

The team members from the Czech Republic and Slovakia themselves or together with their collaborators wrote several case studies devoted to the German mathematical community and the Czech mathematical community. In the first place, it is necessary to mention the English written study titled "Gerhard Hermann Waldemar Kowalewski and His Two Prague Periods", which was written by Martina Bečvářová in 2018 (see Bečvářová 2018c). It was published in the prestigious Polish journal Antiquitates Mathematicae, which is devoted to the history of mathematics in Poland as well as Europe. Based on a deep and extensive study of various sources, the article evaluates the professional activities and personal life of Gerhard Hermann Waldemar Kowalewski (1876-1950), a famous German mathematician. It mainly concentrates on his two Prague periods, 1909-1920 and 1939-1945, which had not been sufficiently covered and discussed in the literature.

Four articles were published in the Czech journal Pokroky matematiky, fysiky a astronomie: Libor Koudela, Jiř́ Veselý: "Felix Hausdorff (18681942)" (2018), Martina Bečvářová: "František Velísek (1877-1914)". “Jak zahynul v první světové válce?” [František Velísek (1877-1914). How did he die in the First World War?] (2019b), Vojtech Bálint, Martina Bečvářová: "Otto Varga - mad'arsko-německý matematik a Praha" [Otto Varga - the Hungarian-German mathematician and Prague] (2020) 
and Jirŕ Veselý: "Otto Eduard Neugebauer (1899-1990)" (2020). The articles describe political, cultural, social as well as scientific changes induced by WWI and WWII and their huge and tragic impacts on the professional activities of selected mathematicians. The texts follow their fascinating life events and their most important mathematical results and activities. They also recall the forgotten or little-known Czech and German mathematicians, some of whom worked in the Czech lands and influenced the teaching of mathematics at the Czech and German prestigious universities.

\section{Presentations of the results in front of the international public}

From the very beginning, the team members were aware that they had to also present their work at international and national conferences. The results were shown at the international conferences in Austria, Czech Republic, Greece, Hungary, Poland, and Slovakia. The results were also presented at many national seminars, workshops, lectures for students, teachers, and people who like mathematics, such as The $38^{\text {th }}$ International Conference on the History of Mathematics (Czech Republic, 2018), XIV. Österreichisches Symposion zur Geschichte der Mathematik (Austria, 2018), The $4^{\text {th }}$ Conference of Mathematics and Computer Science "Congressio-Mathematica" (Poland, 2018), Dickstein Forum (Poland, 2019), The First Conference of the International Academy of the History of Science (Greece, 2019), Dimensional Analysis and Topology (Ukraine, 2019), The $5^{\text {th }}$ Conference of Mathematics and Computer Science "Congressio-Mathematica" (Poland, 2019), The 39th International Conference on History of Mathematics (Czech Republic, 2020) and The $6^{\text {th }}$ Conference of Mathematics and Computer Science "CongressioMathematica" (Poland, 2020).

In 2018, the team members prepared The $38^{\text {th }}$ International Conference on the History of Mathematics (Aug 24-28, 2018, Poděbrady, Czech Republic). The program committee was composed of Martina Bečvárová (chair), Jindřich Bečvár̆, Ivan Netuka, Antonín Slavík and Jiří Veselý (Czech Republic), Vojtech Bálint (Slovakia), Stanisław Domoradzki and Roman Duda (Poland) and Margaret Stawiska-Friedland (USA). About 40 participants from the Czech Republic, Poland, Slovakia, and the USA (historians of mathematics, mathematicians, teachers, $\mathrm{PhD}$ students, students, and people interested in the history of mathematics) took 
part in the conference. The topic of the conference was the impact of WWI on the formation and transformation of the scientific life of the mathematical community. The program consisted of 10 plenary lectures, 5 shorter presentations, and discussions. The team members had a great opportunity to present the results of their research and compare their conclusions with the findings of other specialists in the history of mathematics. ${ }^{14}$

In 2019, team members were active in the organization of the international conference Dickstein Forum (September 19-21, 2019, Kraków, Poland). The program committee was composed of Roman Duda (chairman), Sergei Sergeevich Demidov (Russia), Michał Kokowski, Leokadia Białas-Cież, Roman Murawski, Jarosław Włodarczyk, Jan Woleński, Andrzej Kajetan Wróblewski and Mykhaylo Zarichnyi (Poland), Taras Banakh (Ukraine), Martina Bečvářová (Czech Republic), the local committee was made up of Stanisław Domoradzki (chairman), Margaret Stawiska-Friedland (USA) and Katarzyna Garwol (Poland). About 50 participants from Poland, the Czech Republic, Latvia, Russia, Greece, Ukraine, and the USA (historians of mathematics, logicians, philosophers, mathematicians, teachers, $\mathrm{PhD}$ students, and people interested in the history of mathematics) took part in the conference. The topic of the conference was the development of mathematics in the Central and Eastern Europe in the first third of the 20th century. The program consisted of 16 plenary lectures, 9 shorter presentations, and discussions. ${ }^{15}$

In 2020, the team prepared and organized The 39th International Conference on the History of Mathematics (August 21-25, 2020, Poděbrady, Czech Republic). The program committee was composed of Martina Bečvářová (chair), Jindřich Bečvář, Ivan Netuka, Antonín Slavík and Jiří Veselý (Czech Republic), Vojtech Bálint (Slovakia), Stanisław Domoradzki and Roman Duda (Poland) and Margaret Stawiska-Friedland (USA). More than 30 participants took part and some of them presented the results of their research. Eight members of the team presented their lectures there. It might seem that this conference was not successful. However,

${ }^{14}$ For more information on the international conference on the history of mathematics organized by the team, see the 38th International Conference on History of Mathematics 2018; see also the report on the conference, i. e. Slavík 2018b.

${ }^{15}$ For more information on the conference, see Dickstein Forum 2019. 


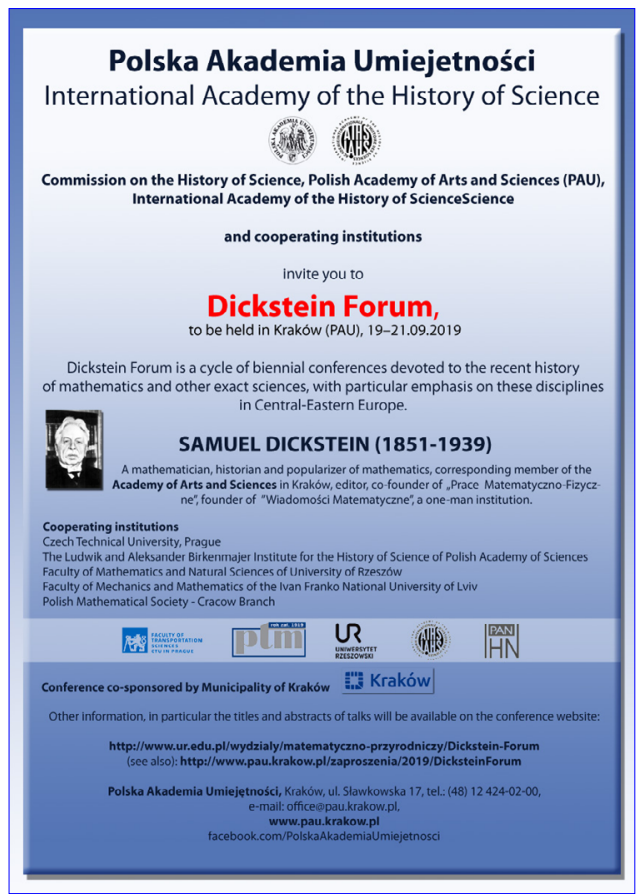

Fig. 3: Promotional poster of Dickstein Forum. Author: Stanisław Domoradzki, 2019.

the opposite is true, as it took place despite the global COVID pandemic. It was one of the few conferences to be held face-to-face. Many other conferences were canceled or brought online. Our conference welcomed participants from the Czech Republic, Poland, Slovakia, and the USA. The participants had enough time to discuss the topics presented in the individual lectures. ${ }^{16}$

Thanks to the lectures at international events, the team established cooperation with many other historians of mathematics, resp. historians of science. The team was able to correct their research trends and tasks and compare the methods of their work with the most modern world trends. The team members planned to present the results at other international conferences, but the COVID epidemic thwarted their plans.

${ }^{16}$ For more details on the international conference on the history of mathematics, see the 39th International conference on the History of Mathematics 2020. See also Bečvár 2020 (the report on the conference). 
Martina Bečvářová, Stanisław Domoradzki

Mathematics in the interwar period in Central-Eastern Europe...

\section{Popularization of the results of the project}

During the execution of the project, it turned out that it was necessary to present the results of the research to the general public, which had no expertise in mathematics or the history of science. Today, without quality popularization, no project can be successful.

The Polish part of the team prepared three exhibitions. The first exhibition was designed by Stanisław Domoradzki and Urszula Foryś and was named "O matematyce i matematykach w stulecie Polskiego Towarzystwa Matematycznego" [On mathematics and mathematicians on the $100^{\text {th }}$ anniversary of the Polish Mathematical Society]. It took place in the Senate of the Republic of Poland (Warsaw). Firstly, it was focused on the presentation of the foundation, development, and scientific and educational role of mathematical communities in Kraków, Lwów, Poznań, Warsaw, and Wilno (in the last 100 years). Secondly, it showed the role of mathematics in the daily life of the contemporary society. ${ }^{17}$
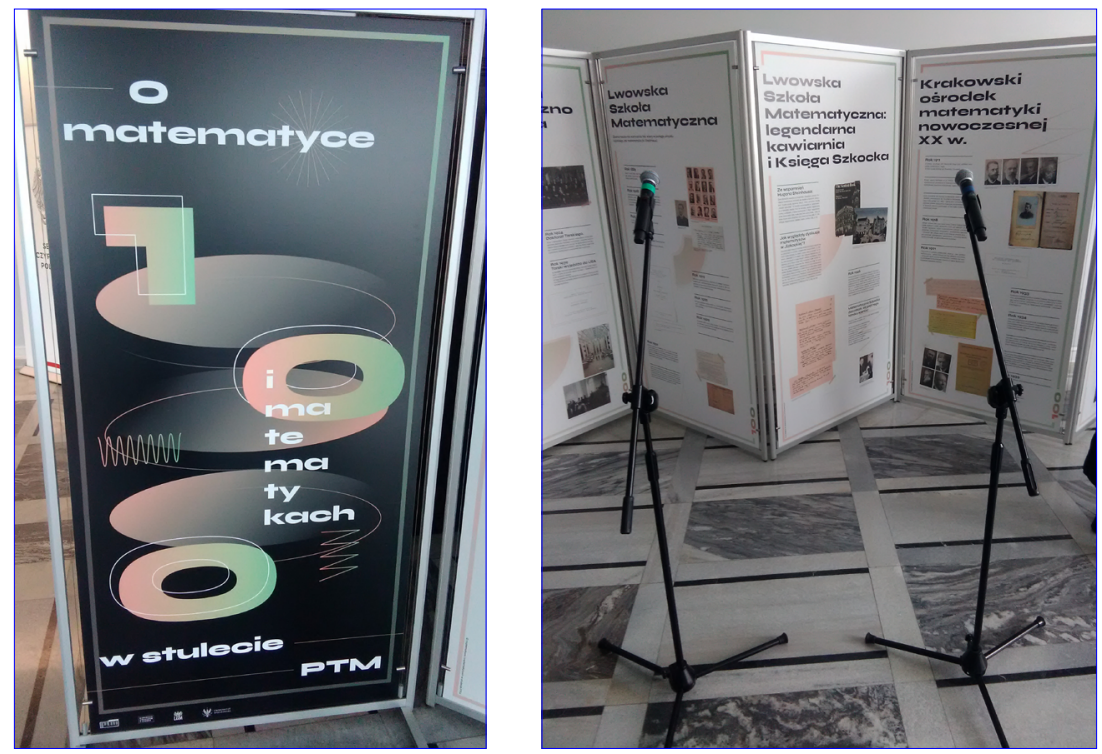

Fig. 4. The photos of the exhibition panel from the exhibition in the Senat. Author: Stanisław Domoradzki, 2019.

${ }^{17}$ For interesting information about the exhibition, see Wystawa w Senacie Rzeczypospolitej Polskiej 2019. 
The second exhibition titled "Założyciele Towarzystwa Matematycznego w Krakowie i działalności PTM do 1936 r." [The founders of the Mathematical Society in Kraków and the activity of the Polish Mathematical Society until 1936] was prepared by Stanisław Domoradzki. It was opened at "The Jubilee Congress of Polish Mathematicians on the $100^{\text {th }}$ Anniversary of the Polish Mathematical Society". The big beautiful exhibition panels were placed in the Auditorium Maximum of the Jagiellonian University in Kraków. The exhibition was devoted to the activities of the Polish mathematicians from 1919 until 1936. It was visited and appreciated by many Polish mathematicians from Poland and around the world. ${ }^{18}$

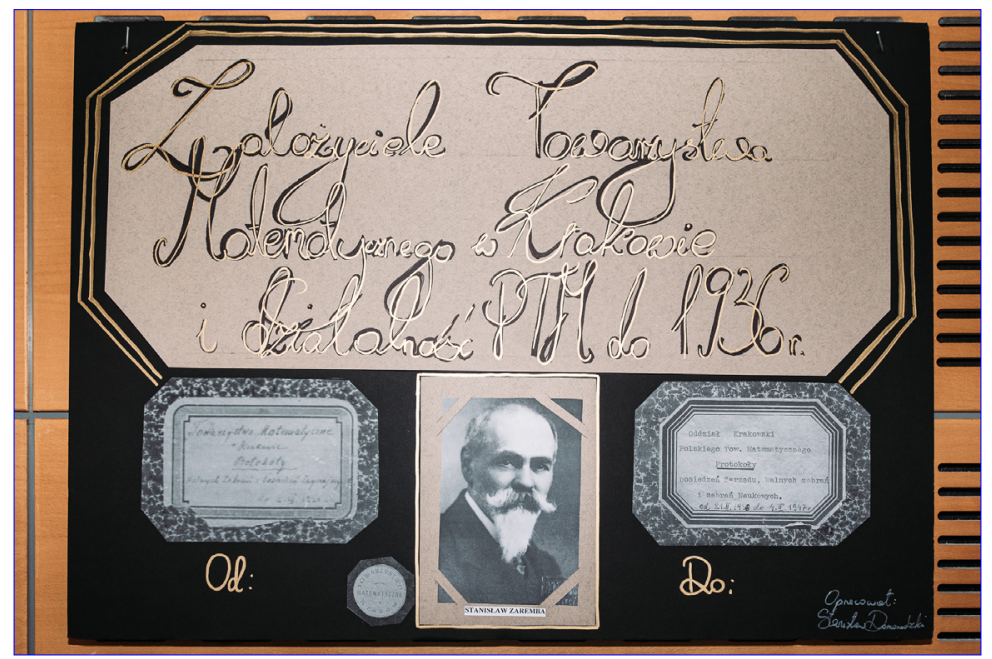

Fig. 5: The photo of the exhibition panel from the exhibition Zatosyciele Towaryystwa Matematycznego w Krakowie i driatalność PTM w Krakowie do $1936 r$. in Audytorium Maximum of the Jagiellonian University in Cracow. Author: Aleksandra Dudziak, 2019.

The third exhibition, "Założyciele Towarzystwa Matematycznego w Krakowie i działalności PTM do 1936 r.” [The founders of the Mathematical Society in Kraków and the Activity of the Polish Mathematical Society until 1936] was created by Stanisław Domoradzki.

${ }^{18}$ For more information on the exhibition, see Jubileuszowy Zjazd Matematyków Polskich w stulecie PTM 2019, and see also Wystawa „O matematyce i matematykach w 100-lecie PTM” 2019. 
It was an integral part of the international conference "Dickstein Forum", which was organized by the Polish Academy of Arts and Sciences in Kraków. The exhibition was dedicated to the founders of the Polish Mathematical Society and its activities in the interwar period and it was visited by people from Poland, the Czech Republic, Latvia, Russia, Greece, Ukraine, and the USA who could recognize the most important facts from the history of Polish mathematical community. ${ }^{19}$

The Czech members of the team wrote articles for the special journal Maskil published by the Jewish community in the Czech Republic, which popularized their original research activities and other results connected with the project. They presented fascinating and tragic lives of some prominent Jewish mathematicians from Germany and Czechoslovakia (for example Saly Ruth Ramler, Hilda Geiringer, Felix Hausdorff, Richard Edler von Mises, Otto Blumenthal, Heinrich Löwig). ${ }^{20}$

The Polish and Czech part of the team also gave some lectures for teachers, $\mathrm{PhD}$. students and students at the Czech and Polish national seminars, conferences, summer schools, and at the special courses on the history of mathematics or history of sciences, technologies, and philosophy. Two members prepared a special academic course for U3W (University for Seniors) for the school year 2020/2021. They gave 16 lectures on the impact of WWI on the changes, development, and transformation of mathematical schools and communities operating in Czechoslovakia in the interwar period. They also focused on the activities of mathematicians in the Central European, European, and world contexts. The lectures attracted a number of seniors, although presentations had to be held online due to the COVID epidemic. ${ }^{21}$

\section{Conclusion}

The project brought together collaborators from the Czech Republic, Poland, Slovakia, Ukraine, and the USA. The project team members also actively collaborated with mathematicians, historians, historians

${ }^{19}$ For more information on the exhibition and the conference, see Domoradzki 2020.

20 The articles are online available online, see Archiv Maskil 2021.

${ }^{21}$ More information on the U3W course which took part at the Faculty of Mathematics and Physics of Charles University can be found in Bečvář, Bečvářová 2021. 
of mathematics and science from Austria, Italy, the Czech Republic, France, Germany, Greece, Hungary, Poland, Russia, Slovakia, Ukraine, the USA. The project created a good platform for future international research and cooperation and other projects. Many new results were obtained but also many new questions and problems were discovered. The team members hope that they will be able to continue their activities and obtain new results in the future.

\section{Acknowledgments}

The research for this article was supported by the project "The Impact of WWI on the Formation and Transformations of the Scientific Life of the Mathematical Community" (GA CR 18-00449S).

\section{References}

Archiv Maskil 2021. Available online: $\underline{\text { https://www.bejtsimcha.cz/archiv-maskil. }}$

Aubin, David; Goldstein, Catherine 2014: The War of Guns and Mathematics: Mathematical Practices and Communities in France and its Western Allies Around World War I. Series History of Mathematics, Volume 42. Providence, RI: American Mathematical Society, 351 pages, ISBN 9781470414696.

Bálint, Vojtech 2019: Lipót Fejér (1880-1959). Obzory matematiky, fyziky a informatiky 48 (4), pp. 11-17 (Slovak).

Bálint, Vojtech 2020a: Hungarian Mathematics Development Stimuli. Antiquitates Mathematicae 14, pp. 39-53. Available online: https://wydawnictwa.ptm.org. $\mathrm{pl} /$ index.php/antiquitates-mathematicae/article/view/7050.

Bálint, Vojtech 2020b: Ferenc Kárteszi. Obzory matematiky, fyzikyy a informatiky 49 (2), pp. 23-26 (Slovak).

Bálint, Vojtech 2020c: Rátz László - učitel' géniov [Rátz László - Teacher of Geniuses]. Obzory matematiky, fyriky a informatiky 49 (4), pp. 22-28 (Slovak).

Bálint, Vojtech 2020d: Pál Erdós trocbu inak [Pál Erdős - A Little Differently]. Pokroky matematiky, fyziky a astronomie 65 (4), pp. 253-260 (Slovak). The article will be available online in $2021 \mathrm{at}$ https://dml.cz/handle/10338.dmlcz/148479.

Bálint, Vojtech; Bečvářová, Martina 2020: Otto Varga - mad’arsko-německý matematik a Praha [Otto Varga - Hungarian-German Mathematician and Prague]. Pokroky matematiky, fyziky a astronomie 65, nr. 1, pp. 36-55 (Czech). Available online: https://dml.cz/bitstream/handle/10338.dmlcz/148115/ PokrokyMFA_65-2020-1_4.pdf. 
Bečvár̆, Jindřich 2007: Z historie lineárni algebry [From the History of Linear Algebra]. Series Déjiny matematiky [History of Mathematics], Volume 35. Praha: Matfyzpress, 519 pages, ISBN 978-80-7378-036-4 (Czech). Available online: https://dml.cz/handle/10338.dmlcz/400920.

Bečvář, Jindřich 2016: 37. mezinárodní konference historie matematiky [The $37^{\text {th }}$ International Conference on History of Mathematics]. Pokroky matematiky, fyziky a astronomie 61(3), pp. 248-249 (Czech). Available online: https://dml. cz/bitstream/handle/10338.dmlcz/145850/PokrokyMFA_61-2016-3_6.pdf.

Bečváŕ, Jindřich 2020: 39. mezinárodní konference historie matematiky [The 39 ${ }^{\text {th }}$ International Conference on History of Mathematics]. Pokroky matematiky, fyziky a astronomie 65(3), pp. 191-192 (Czech).

Bečvář, Jindřich; Bečvářová, Martina 2019: Matematika v obdobi 1918 až 1950 [Mathematics in the Period 1918 to 1950], pp. 467-491. In Kraus Ivo et al. 2019: Věda v ̌̌eských zemich. Dëjiny fyziky, geografie, geologie, chemie a matematiky [Science in the Czech Lands. History of Physics, Geography, Geology, Chemistry and Mathematics]. Praha: Česká technika - nakladatelství ČVUT, 556 pages, ISBN 978-80-01-06557-0 (Czech).

Bečvář, Jindřich; Bečvářová, Martina 2020a: Jarnike's Notes of the Lecture Course Allgemeine Idealtheorie by B. L. van der Waerden (Göttinten 1927/1928). Series History of Mathematics as its volume 64. Prague: Matfyzpress, 251 pages, ISBN 978-80-7378-418-8. Available online: https://dml.cz/handle/10338.dmlcz/ 404406.

Bečvář, Jindřich; Bečvářová, Martina (eds.) 2020b: Matematický svět mezi válkami [The Mathematical World between Wars]. Volume 65, Series History of Mathematics, České vysoké učení technické v Praze, Ústav aplikované matematiky Fakulty dopravní ČVUT, Praha, 352 pages, ISBN 978-80-01-06792-5 (Czech). The book will be soon available online: https://dml.cz/handle/10338. dmlcz/400597.

Bečvář, Jindřich; Bečvářová, Martina 2021: Dopady první světové války na matematickou komunitu ve střední Evropě, Univerzita třetího věku 2020/2021 [The Impact of WWI on the Mathematical Community in the Central Europe, University for Senior 2020/2021] (Czech). Available online: https://www. fd.cvut.cz/personal/becvamar/U3V-2020-2021-b.

Bečvářová, Martina 2016: Matematika na Nèmecké univerzitě v Praze v letech 1882 a气̌ 1945 [Mathematics at the German University in Prague from 1882 until 1945]. Praha: Karolinum, 404 pages + 42 pictures, ISBN 978-80-246-3182-0 (Czech).

Bečvářová, Martina 2018a: Saly Ruth Struik, 1894-1993. The Mathematical Intelligencer 40 (4), pp. 79-85. 
Bečvářová, Martina 2018b: Zrod Mezinárodní komise pro vzdělávání matematice a její aktivity v letech 1908-1939 [Birth of the International Commission for Mathematics Education and its Activities in 1908-1939]. Obrory matematiky, fyziky a informatiky 47 (2), pp. 1-24 (Czech).

Bečvářová, Martina 2018c: Gerhard Hermann Waldemar Kowalewski and His Two Prague Periods. Antiquitates Mathematicae 12, pp. 111-159. Available online: https://wydawnictwa.ptm.org.pl/index.php/antiquitates-mathematicae/ article/view/6386.

Bečvářová, Martina 2019a: Doktorky matematiky na univerzitách v Praze 1900-1945 [Female Doctors of Mathematics at the Universities of Prague 1900-1945]. Praha: Univerzita Karlova v Praze, Nakladatelství Karolinum, 274 pages, ISBN 978-80-246-3991-8 (Czech).

Bečvářová, Martina 2019b: František Velísek (1877-1914). Jak zahynul v první světové válce? [František Velísek (1877-1914). How Did He Die in the First World War?]. Pokroky matematiky, fyziky a astronomie 64, nr. 3, pp. 161-181 (Czech). Available online: https://dml.cz/bitstream/handle/10338.dmlcz/147885/ PokrokyMFA 64-2019-3 4.pdf.

Bečvárová, Martina 2020: Women and Mathematics at the Universities in Prague. [n:] E. Kaufholz, N. M. R. Oswald (eds.) 2020: Against All Odds - Women's Ways to Mathematical Research since 1800. Series Women in the History of Philosophy and Sciences, Volume 6. Springer Nature Switzerland AG, xxi +319 pages, ISBN 978-3-030-47609-0, pp. 73-111.

Bečvářová, Martina (ed.) 2021: The Development of Mathematics Between the World Wars. Case Studies, Examples and Analysis. London - Singapore: World Scientific, 624 pages, ISBN 978-1-78634-930-9.

Bečvářová, Martina; Netuka, Ivan 2018: Cesta ke vzniku Fieldsovy medaile [Tracing the Origins of the Fields Medal]. Pokroky matematiky, fyzikey a astronomie 63, nr. 1, pp. 13-27 (Czech). Available online (paid access): https://www.dml. cz/bitstream/handle/10338.dmlcz/147206/PokrokyMFA 63-2018-1 2.pdf.

Bečvářová, Martina; Netuka, Ivan 2019: Dopady prvni svètové války na mezinárodní spolupráci matematiku [The Impact of the First World War on the International Cooperation of Mathematicians]. Praha: České vysoké učení technické v Praze, Česká technika - nakladatelství ČVUT, 240 pages, ISBN 978-80-01-06540-2 (Czech).

Brizzi, Gian Paolo; Signori, Elisa (eds.) 2017: Minerva armata. Le università e la Grande guerra. Bologna: CLUEB Casa editrice, X + 258 pages, ISBN 978-88-4915540-2.

Centro interuniversitario per la storia delle università italiane - CISUI 2016: Minerva armata. Le università e la Grande guerra - Convegno internazionale. 
Martina Bečvářová, Stanisław Domoradzki

Mathematics in the interwar period in Central-Eastern Europe...

Available online: https://www.academia.edu/29776552/Minerva armata Le universit $\% \mathrm{C} 3 \% \mathrm{~A} 0$ e la Grande guerra Convegno internazionale.

Czech Science Foundation 2020. Available online: https://gacr.cz/en/.

Dickstein Forum 2019. Available online: http://pau.krakow.pl/index.php/pl/ aktualnosci-2/1557-dickstein-forum.

Domoradzki, Stanisław; Stawiska, Margaret 2015a: Distinguished Graduates in Mathematics of Jagiellonian University in the Interwar Period 1918-1925. Technical Transactions - Fundamental Sciences, Issue NP 2, pp. 99-115.

Domoradzki, Stanisław; Stawiska, Margaret 2015b: Distinguished Graduates in Mathematics of Jagiellonian University in the Interwar Period. Part II: 19261939. Technical Transactions - Fundamental Sciences, Issue NP 2, pp. 117-141.

Domoradzki, Stanisław; Stawiska Margaret 2018: Polish Mathematicians and Mathematics. In World War I. Part I: Galicia (Austro-Hungarian Empire). Studia Historiae Scientiarum 17, pp. 23-49. DOI: 10.4467/2543702XSHS. 18.003.9323. Available online: https://ojs.ejournals.eu/SHS/article/view/ SHS.18.003.9323/6795.

Domoradzki, Stanisław; Stawiska, Margaret 2019: Polish Mathematicians and Mathematics in World War I., Part II. Russian Empire. Studia Historiae Scientiarum 18, pp. 55-92. DOI: $10.4467 / 2543702 X S H S .19 .004 .11010$. Available online: https://ojs.ejournals.eu/SHS/article/view/6903/6830.

Domoradzki, Stanisław 2020: Dickstein Forum. Kwartalnik Historii Nanki i Techniki 65(1), pp. 167-169 (Polish). Available online: https://www.ejournals.eu/ KHNT/2020/1-2020/art/16338/.

Domoradzki, Stanisław ; Stawiska, Margaret; Zarichnyi, Michael 2021: O znaczeniu Księgi Szkockiej. W 85. rocznicę jej założenia / On the importance of the Scottish Book. On the 85th anniversary of its foundation. Komisja Historii Nauki PAU, 17 lutego 2021. Available online: https://zenodo.org/record/ 4588879\#.YNmZ-yBR2Uk.

Duda, Roman 2014: Pearls from a Lost City. The Lvov School of Mathematics. Providence, RI: American Mathematical Society, 231 pages, ISBN 9781470410766.

Duda, Roman 2018: One Hundred Years of the Polish Mathematical Society. Antiquitates Mathematicae 12, pp. 3-30. Available online: https://wydawnictwa. ptm.org.pl/index.php/antiquitates-mathematicae/article/view/6422.

Duren, Peter L.; Askey, Richard A.; Merzbach Uta C. 1988-1989: A Century of Mathematics in America. Part I.-III. Series History of Mathematics. Providence, RI: American Mathematical Society, $477+585+675$ pages, ISBN 0-82180124-4, 0-8218-0130-9, 0-8218-0136-8. 
Goldstein, Catherine; Gray, Jeremy; Ritter, Jim (eds.) 1996: L'Europe mathématique mythes, histories, identités. Paris: Edition de la Maison des Sciences de l'Homme, 575 pages, ISBN 9782735106851.

Janout, Zdeněk 2019: I. Kraus a kol.: Věda v českých zemích: Dějiny fyziky, geografie, geologie,chemie a matematiky [I. Kraus et all.: History of Physics, Geography, Geology, Chemistry and Mathematics]. Rozhledy matematicko-fyzikálni 94(4), pp. 52-54 (Czech). Available online: https://dml.cz/bitstream/ handle/10338.dmlcz/148017/Rozhledy 094-2019-4 7.pdf.

Jubileuszowy Zjazd Matematyków Polskich w stulecie PTM 2019: Available online: https://100latptm.matinf.uj.edu.pl/wystawa-o matematyce.php.

Koudela, Libor; Veselý, Jiří 2018: Felix Hausdorff (1868-1942). Pokroky matematiky, fyziky a astronomie 63 (2), pp. 108-124 (Czech). Available online: https://dml. cz/bitstream/handle/10338.dmlcz/147327/PokrokyMFA 63-2018-2 4.pdf.

Mazliak, Laurent; Tazzioli, Rossana (eds.) 2021: Mathematical Communities in the Reconstruction After the Great War 1918-1928. Trajectories and Institutions. Series Trends in the History of Science. Brikhäuser, Springer Nature Switzerland AG, 363 pages, ISBN 978-3-030-61682-3.

Netuka, Ivan 1995: Mezinárodní matematické kongresy a Fieldsovy medaile [International Congresses of Mathematicians and Fields Medals]. Pokroky matematiky, fyziky a astronomie 40 (3), pp. 124-129 (Czech). Available online: https:// dml.cz/bitstream/handle/10338.dmlcz/139061/PokrokyMFA 40-1995-3 3. pdf.

Netuka, Ivan 2018: Cesta k pojmu kompaktního operátoru Journey to the Concept of a Compact Operator]. Pokroky matematiky, fyziky a astronomie 63 (3), pp. 153-174 (Czech). Available online: https://www.dml.cz/bitstream/handle/ 10338.dmlcz/147441/PokrokyMFA 63-2018-3 1.pdf.

Netuka, Ivan 2020: Lebesgue's Criticism of Carl Neumann's Method in Potential Theory. Archive for History of Exact Sciences 74, pp. 77-108.

Pier, Jean-Paul (ed.) 1994: Development of Mathematics 1900-1950. Lectures from the Symposium held in Luxembourg, June 1992. Basel: Birkhäuser Verlag, 734 pages, ISBN 9783034891141.

Slavík, Antonín 2007: Product Integration, Its History and Applications. Series History of Mathematics, Volume 29. Prague: Matfyzpress, 147 pages, ISBN 80-7378006-2. Available online: https://dml.cz/handle/10338.dmlcz/401129.

Slavík, Antonín 2018a: Hallova věta, její aplikace a historie [Hall's Marriage Theorem, Its Applications and History]. Pokroky matematiky, fyziky a astronomie 63 (3), pp. 175-195 (Czech). Available online: https://www.dml.cz/bitstream/ handle/10338.dmlcz/147443/PokrokyMFA 63-2018-3 2.pdf. 
Slavík, Antonín 2018b: 38. mezinárodní konference historie matematiky [The $38^{\text {th }}$ International Conference on History of Mathematics]. Pokroky matematiky, fyziky a astronomie 63(3), pp. 227-228 (Czech). Available online: https://dml. cz/bitstream/handle/10338.dmlcz/147446/PokrokyMFA 63-2018-3 5.pdf.

Slavík, Antonín 2019a: Unbiased Version of Hall's Marriage Theorem in Matrix Form. The American Mathematical Monthly 126( 9), pp. 835-837.

Slavík, Antonín 2019b: Martina Bečvářová a Ivan Netuka: Dopady první světové války na mezinárodní spolupráci matematikủ [Martina Bečvářová and Ivan Netuka: The Impact of the First World War on the International Cooperation of Mathematicians]. Pokroky matematiky, fyziky a astronomie 64(2), pp. 123-124 (Czech). Available online: https://dml.cz/bitstream/handle/10338. dmlcz/147807/PokrokyMFA 64-2019-2 6.pdf.

Springer 2020: Springer against all odds women's ways to mathematical research since 1800. Available online: https://www.springer.com/gp/book/9783030476090.

Suzuki, Jeff 2009: Mathematics in Historical Context. Washington, DC: Mathematical Association of America Spectrum, The Mathematical Association of America, 409 pages, ISBN 9780883855706.

Tesařík, Bohumil 2020: Historie přirodních věd v českých zemích [History of Nature Sciences in the Czech Lands] (Czech). Available online: https://www. 3pol.cz/cz/rubriky/recenze/2527-historie-prirodnich-ved-v-ceskych-zemich.

$38^{\text {th }}$ International Conference on History of Mathematics 2018. Available online: https://www.fd.cvut.cz/personal/becvamar/konference/konference-2018/ index.html.

$3^{\text {th }}$ International Conference on History of Mathematics 2020. Available online: https://www.fd.cvut.cz/personal/becvamar/konference/index.html.

Trkovská, Dana 2019: Martina Bečvářová: Doktorky matematiky na univerzitách v Praze 1900-1945 [Martina Bečvářová: Female Doctors of Mathematics at the Universities of Prague 1900-1945]. Pokroky matematiky, fy ziky a astronomie 64(2), pp. 125-126 (Czech). Available online: https://dml.cz/bitstream/ handle/10338.dmlcz/147807/PokrokyMFA 64-2019-2 6.pdf.

Vekerdi, László 1996: A Tudománynak háza vagyon [Science Has a Home]. Budapest: Magyar Tudománytörténeti Intézet, Piliscsaba, 227 pages (Hungarian).

Veselý, Jiří 2020: Otto Eduard Neugebauer (1899-1990). Pokroky matematiky, fyziky a astronomie 65 (1), pp. 19-35 (Czech). Available online: https://dml.cz/ bitstream/handle/10338.dmlcz/148114/PokrokyMFA 65-2020-1 3.pdf.

World Science 2021: Available online: https://www.worldscientific.com/world scibooks/10.1142/q0273. 
Wystawa "O matematyce i matematykach w 100-lecie PTM" 2019: Available online: http://www.jrm2019.pl/rok-matematyki-w-senacie-rp/wystawa-omatematyce-i-matematykach-w-100-lecie-polskiego-towarzystwamatematycznego/.

Wystawa w Senacie Rzeczypospolitej Polskiej - O Matematyce i Matematykach w stulecie Polskiego Towarzystwa Matematycznego 2019: Available online: https://www.ur.edu.pl/uniwersytet/aktualnosci/wystawa-w-senacie-rzeczy pospolitej-polskiej-o-matematyce-i-matematykach-w-stulecie-polskiegotowarzystwa-matematycznego,20571?print $=$ pdf. 